\title{
Capturing Gender Equality and Social Inclusion (GESI) Initiative in Indonesia: Case Studies in Higher Education
}

\author{
Arianti Ina Restiani Hunga ${ }^{1}$; Tundjung Mahatma ${ }^{2}$ \\ \{ina.hunga@uksw.edu ${ }^{1}$, tundjung.mahatma@uksw.edu ${ }^{2}$ \} \\ The Centre for Gender \& Child Studies, Universitas Kristen Satya Wacana ${ }^{1}$; Interdisciplinary Faculty, Universitas Kristen \\ Satya Wacana ${ }^{1}$ \\ Faculty of Science and Mathematics, Universitas Kristen Satya Wacana ${ }^{2}$
}

\begin{abstract}
This paper aims to explain higher education initiatives in integrating Gender Equality \& Social Inclusion (GESI) in education, research \& community service activities. The study was conducted using focus group discussions, in-depth interview, \& secondary data. GESI analysis was conducted to understand and critical reflection on GESI initiation in education \& teaching, research, and community service programs. Although GESI has a strong basis in government policy but not yet an integrated part of the state policy implementation such as the National Development Plan. In line with that the higher education has not yet fully commitment to integrate GESI into management and the three higher education's obligations (education, research, and community services). Even though the numbers are relatively small, there is a movement from the 'bottom' from the lecturers / researchers who already have a GESI perspective
\end{abstract}

Keywords: gender, higher education, Indonesia, social exclusion, social inclusion

\section{Introduction}

The progress of Indonesia in the last decade has been impressive, but there are issues of particular concern, mainly pertaining to religious intolerance [1], gender inequality [2], social exclusion, and environmental destruction. As Indonesia progresses towards higher-income status, many of the poor are trapped in precarious employment relative to other emerging economies, particularly women (gender inequality) [3]. This fact, in turn, requires serious attention, particularly from higher education, in order to assume an active role in producing \& sharing of values of pluralism, justice, peace, and sustainability.

Indonesia has chartered impressive economic growth in recent decades. The nation has gained middle income status and joined the ranks of the G20. Although the progress of Indonesia in the last decade is impressive, there are issues of particular concern, mainly pertaining to religious intolerance, gender inequality, and environmental destruction. In its Year End Report of Religious Freedom, the Wahid Institute reported 190 offenses against religious freedom, which meant an increase to a total of 23\% in comparison to 2014 [1].Women have also seen an improvement in quality of life. Despite this progress, gender inequalities are still entrenched and pervasive in every part of society. Women and girls do not have access to health, employment, participation and decision making equally to men and boys [4]. There is potential for significant gains in the pursuit for gender equality, yet implementation, awareness-raising, breaking down stereotypes and institutional support are necessary to get there. Regarding gender equality, UNDP data show a distinct gap between women $(0.660)$ and men (0.712) in the Human Development Index (HDI) [5]. In the Gender Development Index (GDI), Indonesia scores 0.926, a figure which is lower than, e.g., that for the Philippines [5]. The environmental quality of Indonesia is graded by the National Environmental Quality Index. The index showed a value of 63.42 in 2014, a notable decrease to the figure three years prior (65.76). Indonesia's Water Index scored 52.19 in 2014, indicating that the percentage of polluted water increased from 62\% to 80\% during 2009-2013. The Forest Coverage Index for Indonesia is low as well (59.01). Deforestation in Java and Sumatra was caused mainly by (intentional) burning and change of land use. Only the Index for Air Quality showed an improvement, the value of 80.54 in 2014 is up from 80.17 in 2013 [6]. In global comparison, Indonesia displays rather poor figures, ranking on position 112 out of 178 countries in the Environmental Performance Index in 2014 [7].

Indonesia established a strong policy framework in the implementation of gender equality and social inclusion (GESI). That, however is not proven to be effective, as shown by the high rates of violence based on gender, ethnicity, race, and religious beliefs; this includes the involvement of children and women in radicalism and fundamentalism movement. This shows that GESI is not an integrated part of the state policy implementation such as the National Development Plan for 2015-2019. Gaps exist in the GESI problems in the 
society, GESI-based research and community outreach outcomes, and the policies to achieve GESI. The question exists: What roles do the higher education institutions take?

Since 2003 Gender Mainstreaming (GEM) activities has been actively carried out through the Ministry of Education and Culture programs on, and lower, of high-school levels of education. On higher education level, on the other hand, it seems to be vague, forgotten. There is such an assumption that GESI problems do not exists in higher education. The facts, however, show that very few women gained strategic positions in universities, or achieving professorship. This has implications on the commitment to integrate GESI into the three higher education's obligations.

This paper aims to explain higher education initiatives in integrating Gender Equality \& Social Inclusion (GESI) in education, research \& community service activities. The study was conducted using focus group discussions, in-depth interview, \& secondary data. GESI analysis was conducted to understand and critical reflection on GESI initiation in education \& teaching, research, and community service programs. Although GESI has a strong basis in government policy but not yet an integrated part of the state policy implementation such as the National Development Plan. In line with that the higher education has not yet fully commitment to integrate GESI into management and the three higher education's obligations (education, research, and community services). Even though the numbers are relatively small, there is a movement from the 'bottom' from the lecturers / researchers who already have a GESI perspective

This paper aims to explain higher education initiatives in integrating Gender Equality \& Social Inclusion (GESI) in education, research \& community service activities.. The study was conducted using focus group discussions, in-depth interview, \& secondary data. GESI analysis was conducted to understand and critical reflection on GESI initiation in education \& teaching, research, and community service programs.

\section{Methods}

The study was conducted using Focus Group Discussion and secondary data from: 1. Social Service and Health Office of Central Java and National Level; 2. Statistical Office; 3. Department of Women Empowerment and Child Protection of Central Java and National level; 4. Ministry of Research, Technology, and Higher Education; 5. Centre of Gender Study in all Indonesian universities. Data retrieval techniques is done by secondary data (report and publication of research results from Indonesian universities). NGO, and government. Primary data was explored through Focus Group Discussion among 15 key stakeholders in In Indonesia which related to GESI. The analysis used is GESI analysis. Data analysis used was a qualitative data analysis technique with GESI analysis.

\section{Results and Discussion}

In this section, the authors will describe the findings into three parts, including; a review of Gender Equality \& Social Inclusion (hereinafter abbreviated as GESI) in the literature; a review of the GESI policy in the Indonesian context; and how the portrait of GESI implementation in higher education in case studies.

\subsection{GESI in The Society \& SGDs contends}

Sex and gender are two different concepts, even though they are based on similar basis related to gender (male/female). Sex refers to natural (biological and physical) differences between male and female. Sex for males are shown through his possession of penis, testicles, ability to produce sperms, and having the potential for fertilization when sperms meet an egg. On the other hand, sex for females are shown through vagina, uterus, egg cells, menstruation, having the potential for pregnancy, giving birth, and breastfeeding. This difference is fixed and natural. In contrast, gender considers male/female as a product of social construct (social-cultural) of an individual or a group of people who are associated with their gender (male/female). Therefore, in a community, we have female (feminine) and male (masculine) that they acquire through a long learning process, through labeling, rules, values/norms that determine the position, role, and practice of both genders in every aspect of life as an individual, community, society, and citizen of a country. This also means that gender is not natural, instead, it is 'formed' based on the expectation of a community to be practiced of both sexes. Therefore, gender is not a fixed value, it can change according to time and the context of certain society and culture [8], [9].

In practice, gender is not neutral, it creates unequal power relationship due to patriarchal community base, which further forms the standard values/norms and practices that dominate males rather than females. Patriarchal values and norms create biased ideas, perceptions, and treatments towards women/girls. This can happen systemically because these values/norms are included in formal and informal institutions. Furthermore, these values are adopted in managing people's lives in various aspects, including laws, policies, government mechanisms, and programs. This separation of roles has been going on for a long time in society, and it is taken for granted, even considered as 'truth or natural.' Continued domination creates the inability and powerlessness 
of the dominated group. Therefore, gender roles often marginalize certain groups, especially women. Facts in various countries, including in Indonesia, women and children are part of the marginalized community. In this condition, women experience injustice in various dimensions of life [10].

Achieving gender equality (hereafter, GE) between women, men, and disadvantaged groups requires changes in systems and structures in various levels, including changes in attitudes and relationships, changes in institutions and legal frameworks, changes in economic institutions, and changes in the structure of political decision making [11]. The United Nations defines gender equality as the equality of rights, responsibilities, and opportunities between women and men in various aspects. Therefore, critical education and affirmative policy are needed to 'dismantle' the existing system and structure barriers to provide access, and ensure that women, children, and other marginalized groups acquire their rights.

However, in its development, gender analysis is not enough because marginalization and depreciation that befell women/girls overlap with other identities that are attached to their gender, for example their social class, ethnicity, caste, religion, and body condition. Therefore, gender analysis should be intersectional by including other identities to further explain that they are experiencing various layers of social exclusion. In this case, the use of intersectional approach (cross cutting approach) in gender and social exclusion will help explain how gender intersects with other social identity, as well as making a critical contribution to the reality of oppression and different privileges [12].

Walker \& Walker [13] defined social exclusion as "the dynamic process of being shut out, fully or partially, from any of the social, economic, political and cultural systems which determine the social integration of a person in society." In this case, social exclusion is a forced exclusion of individuals and groups caused by the identities attached to them, which limit their participation in political, economic, and social processes. Social exclusion causes abrasion or the loss of civil, political and social rights as citizens. Excluded communities (exclusions) are marginalized groups based on their minority social identities, which include gender, race, religion, social class, physical limitations (people with disability) and domicile. In the context of women in patriarchal society, unjust practices are not only caused by their gender, but also other minority social identities that are inherent in themselves, for example low caste, disability, religious minorities, and living in remote areas. Women experience injustice due to the burden of their double identity, and the most basic discrimination is caused by their gender.

Related to the social exclusion described above, the fulfillment of the rights of marginalized groups through affirmative process in order to ensure their reintroduction (integration) in the social system can be interpreted as social inclusion. The process of social integration for disadvantaged and marginalized people in society aims to create a process of reunification in the dynamic process of society [14]. Therefore, social inclusion can be defined as "the effort to remove institutional barriers coupled with an increase of incentives for the people who are ostracized to increase access of individuals in diverse groups in the development process" [15]. Through this process, those who are disadvantaged for their identity can regain their dignity, opportunity, and access to improve their skills to take part in various aspects of life in society.

In studies related to gender and GE as well as social exclusion and inclusion, there are two pairs of integrated concepts (intersectional) into one unit. Gender Equality and Social Inclusion (hereafter, GESI) becomes the fundamental aspect of human rights and social justice, and it becomes a prerequisite for achieving sustainable development goals. There are three Sustainable Development Goals (SDGs) related to GESI. They are SDG \#1 (eliminating absolute poverty and reducing poverty by half), SDG \#5 (gender equality and empowering women and girls), and SDG \#10 on reducing inequality (within and between countries) by 2030 [4].

GESI integration in policies and programs can be interpreted as a process and strategy to ensure that women and men from all social groups (ethnic, religious, economic, age, disability, and geographical location) are integrated into policies and programs from planning, implementation, monitoring, and project evaluation in all fields. It aims to promote equality, fairness, and strengthening legitimacy by addressing the existing gaps. Through this process, women and men will have equal access and control over resources, public services, information and opportunities as well as the distribution of power and decision making [16], [17]. The Knowledge Sector Initiative ${ }^{1}$ [18]-[21] added that in Indonesia, it is very important for policymakers to apply GESI perspective to ensure the achievement of poverty alleviation target and continuous economic growth. In this case, policymakers understand the nature and degree of social inequality and exclusion of the marginalized groups and the impacts of policy on them. In Nepal, GESI Working Group as a focal point at the national level massively paid attention to three national priority issues and made them three strategic areas to achieve GESI. These three national priorities were 1) the rights to be represented and participate in decision making, 2) the rights to equal distribution in human development, and 3) the rights to recognition in culture and language

\footnotetext{
${ }^{1}$ is a partnership between the governments of Indonesia and Australia
} 
diversity. The study in Nepal showed that GESI Interaction benefitted in terms of 1) achieving program effectiveness and sustainability, 2) encouraging participation from different program subjects to achieve program goals for all and its sustainability, 3) stakeholder participation and coordination, and 4) the occurrence of learning process and knowledge sharing between the parties involved and program subjects.

We can find issues of GESI everywhere, including in Higher Education (hereafter, HE). UNESCO study in Bangkok [22] found that HE in Asia-Pacific region had not given serious attention to gender issues visible in four aspects, which included affirmative policies to provide access to women, greater women's participation in technical and science education, developing women's studies, women's representation in managerial positions, and attention to marginal groups (people with disability, the poor, and those living in remote areas). What about the Higher Education in Indonesia? This article will attempt to portray GESI in Higher Education institutions in Indonesia, especially those under the Ministry of Research, Technology, and Higher Education (Kemenristekdikti) of Republic Indonesia.

\subsection{GESI in Indonesian Policy}

Indonesia already has a strong policy framework and commitment towards GESI, which include Sustainable Development Goals (SDGs) from Agenda 2030. These commitments are grouped into two parts. First, gender equality which is included in the 1945 Constitution (Article 27: 1 and 2; Article 28H: 1-3; Article 28 I: 2; Article 34: 2), the Convention on the Elimination of All Forms of Discrimination Against Women (CEDAW) which was ratified through Law No. 7 of 1984, Presidential Instruction No. 9 of 2000 on Gender Mainstreaming in National Development, the Regulation of the Ministry of Home Affairs No. 15 of 2008 on the Guidelines for Implementing Gender Mainstreaming in Regions, Law No. 23 of 2004 on the Elimination of Domestic Violence, the Regulation of the Ministry of Home Affairs No. 67 of 2011 on the General Guidelines for Implementing Gender Mainstreaming in Regions, Joint Circular Letter of 2012 related to the national strategy for accelerating gender mainstreaming through gender responsive planning and budgeting, Government Regulation No. 43 of 2014 (Article 1, paragraph 1) on the implementation of activities in village development based on gender equality approach.

Secondly, policies related to gender equality and social inclusion. They are Law No. 40 of 2008 on the elimination of racial and ethnic discrimination, the ratification of the UN Convention on the Rights of People with Disabilities through Law No. 19 of 2011 and Law No. 8 of 2016 on people with disabilities, Law No. 6 of 2014 on the implementation of GESI in the village government, 2015-2019 and 2020-2024 National Medium Term Development Plan which provide affirmations on inclusive development for women, people with disabilities, minority indigenous groups and other vulnerable groups, Government Regulation No. 75 of 2015 , and the Presidential Instruction on National Human Rights Action Plans, Guidelines for planning and budgeting that are responsive to people with disability in 2015, Law No. 8 of 2016 on disability, and the Presidential Regulation No. 59 of 2017 on the Implementation of Achieving Sustainable Development Goals related to SDG 1 (eliminating absolute poverty and reducing poverty by half), SDG 5 (gender equality and empowering women and girls), and SDG 10 on reducing inequality (within and between countries).

However, the national efforts in realizing GESI had not been effective because at the empirical level, the number of gender-based violence and social exclusion remained relatively high. The report by Komnas Perempuan (National Commission on Violence against Women) mentioned that gender-based violence continued to rise. In 2016, there were 259,150 women who experienced violence and the number increased to 406,178 people in 2019. Komnas Perempuan also added that 1 out of 8 women are raped every day [23]. Other important data could be seen from the following index: Indonesia's Gender Inequality Index was 0.453, which was on high category, and it was considered above the average for ASEAN countries (0.356); it ranked 4th of ASEAN countries, and ranked 104th out of 189 countries [24], [25]. The WEF report [26] mentioned that the position of Indonesia as seen in the Global Gender Gap Index was 0.70, which ranked 85 out of 153 countries. The environmental quality of Indonesia was evaluated by the National Environmental Quality Index. In global comparison, Indonesia displayed rather poor figures, ranking 133 out of 180 countries in the Environmental Performance Index in 2018 [27].

\subsection{Capturing GESI in Higher Education in Indonesia}

One important aspect in measuring the index above is education. Gender mainstreaming (hereafter, GEM) is a global and national program to study gender inequality in the field of education. Gender Mainstreaming in Higher Education refers to Presidential Instruction No. 9 of 2000. Furthermore, it is further emphasized by the Regulation of the Ministry of National Education No. 84 of 2008 on the Guidelines for Implementing Gender Mainstreaming in Education. It is stated in the Regulation that each work unit in the field of education should integrate gender in all activities. GEM in education by the Ministry of National Education is carried out through five main strategies. They are (1) capacity building for policy makers in each main unit, (2) increasing the capacity of education planners in developing gender responsive planning and budgeting, (3) collaborating with 
women/gender study centers in HE in studying and finding gender issues in each region, (4) cooperating with social organizations, mass organizations, and NGOs in developing models of gender equity education in families and communities, and (5) developing communication, information and education media [28].

As a follow up to this policy, GEM in education was already implemented under the Ministry of Education and Culture since 2013. It was instigated in pre-school, elementary school, middle school, and high school levels. However, the programs remained 'unheard of' and received lack of attention at higher education level. Public attention focused more on higher education institution when media reported the occurrence of several cases of violence, especially sexual violence. Since 2013, any form of violence and/or sexual violence occurring at higher education institution was revealed and became a public discussion. According to the Annual Note of the National Commission on Violence against Women, in 2018 there were 12 cases of sexual violence occurring at higher education institutions [29]. However, there had been no comprehensive data related to gender-based violence, especially of sexual violence and the campus efforts to uphold justice for its victims. LBH APIK [30] revealed that several higher education institutions actually have rules regarding cases of sexual harassment and violence. However, these rules tend to be weak and there is no special mechanisms that will protect the victims, especially women. In terms of regulations at HE institutions, Law No. 12 of 2012 on Higher Education article 6 point (b) mentions that Higher Education is carried out with democratic and fair principles and should not be discriminatory by upholding human rights, religious values, cultural values, pluralism, unity, and national unity. However, the Regulation of the Ministry of Education and Culture has not ratified a specific policy related to the obligation of educational institutions to protect victims and manage violence that had occurred within the realm of educational institutions. Komnas Perempuan [31] emphasized that the lack of curriculum on gender equality in schools, including HE in Indonesia, becomes one factor that contributes to the rising rate of gender violence in educational institutions.

The public and policy makers are shocked because they assume that HE community will have sufficient knowledge, is critical and has good capacity that there will be no problems related to GESI issues. This assumption is further reinforced by referring to quantitative data showing that female and male participation in higher education is relatively similar. However, such quantitative data could not be used to infer the reality of higher education. In order to have better conclusion, one will need in-depth and holistic research to also consider other aspects, which include the policy and management within HE in protecting and ensuring safe nuance within campus so that the academic community, both male and female, will have equal access, participation and control of facilities and resources, education and teaching activities, research and community service projects, as well as the publication of works that will produce quality human resources and studies with GESI perspective ${ }^{2}$. This surely becomes a contradiction because HE has a strategic role to achieve GESI in the context of sustainable development goals (SDGs). It has a strategic role in producing scholars who will produce and distribute knowledge, innovation and technology with GESI perspective. The main question remain on: how is the implementation of GESI in Higher Education related to education and teaching activities, research, community service projects, and the publication of scientific papers?

\subsubsection{Human Resources, Policies, Education and Teaching Activities}

PPDikti data [32] showed that there were 4,621 HE in Indonesia. Out of this number, $70 \%(3,251)$ were under the Ministry of Research, Technology, and Higher Education; 26\% (1,192) were under the Ministry of Religious Affairs; and 4\% (178) were under other Ministries/Institutions. Out of 3,251 HE institutions under the Ministry of Research, Technology and Higher Education, there were 122 (2\%) of state universities and 3,129 $(68 \%)$ private universities. In these higher education institutions, there were 22,684 study programs in total. Ten most popular study programs in Indonesia were management (1,140 programs), accounting (991), Midwifery, Islamic Religious Education, Informatics Engineering, Nursing, Legal Studies, Civil Engineering, Information Systems, and Pharmacy. The data could be seen more clearly in Table 2 below.

\footnotetext{
${ }^{2}$ Focus Group Discussion conducted in 2015 on several different groups at campus
} 


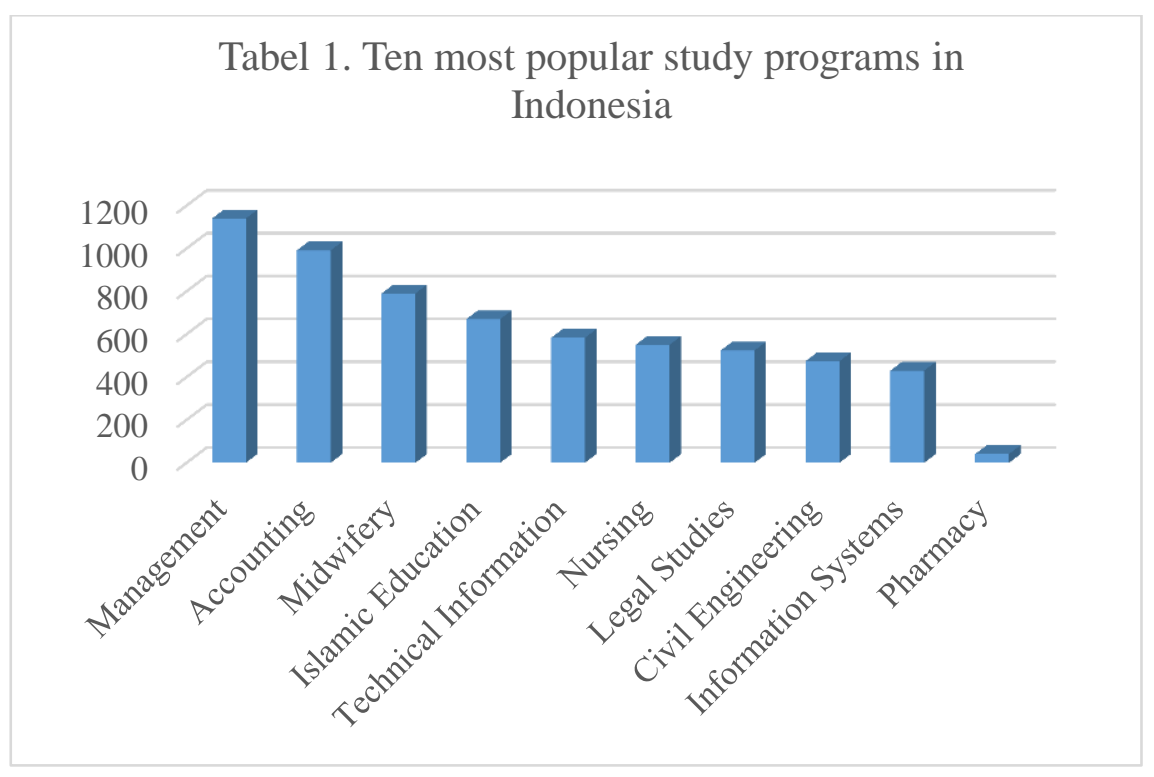

Source: PPDikti in 2019

Judging from the number of students, PPDikti data [33] showed that the number of students was $6,864,015$ and of that number, the number of female students was slightly higher with 3,460,406 (50.4\%) and male students were 3,403,609 (49.6\%). In 2019, the number of students increased to 9,485,050 people, in which there were 4,394,280 male students $(46 \%)$ and 5,090,770 female students $(54 \%)$. The data showed that the number of female college students was higher. Quantitatively, it showed that women's access to higher education was not an obstacle. However, the concern was the female students' pattern of participation in the study program. Did it change the dynamics of higher education to be more gender responsive amidst the persisting concern over gender-based violence in the society?

In the 2015 Rector Forum meeting facilitated by the Ministry of Women's Empowerment and Child Protection (KemenPPPA) and during the $\mathrm{FGD}^{3}$ it was revealed that the segmentation of student choice and orientation was still based towards gender stereotypes. Accounting, midwifery, pharmacy, medicine, biology, and chemistry study programs were mostly dominated by women. Whereas informatics engineering, information technology, and civil engineering were dominated by men. It was also found that the average score of female students was higher than that of men and that they graduated faster. However, there were problems after they graduated, as if the achievement was 'missing' from the equation, the number of women's work participation rates were lower than men [34]. There were indications that after graduation, female students tended to delay their participation in the workforce. There was also a tendency for them to prefer pursuing marriage and family, therefore focusing more on their domestic duties. UNESCO [35] found that in Indonesia and five other countries in Asia-Pacific region, the participation of Indonesian women in higher education was relatively high especially in the fields of science, technology, engineering and mathematics ( $\boldsymbol{S}$ cience, Technology, Engineering, \& Mathematics or STEM). In fact, women dominated with more than $80 \%$ in some fields, such as Biology and Pharmacy study programs. However, this picture changed significantly because the number of women's participation in workforce was quite low. In the field of STEM, only two out of 10 women chose a professional career, and only three out of 10 women became researchers in $\boldsymbol{S T E M}$ field. A reason for women's reluctance in entering $\boldsymbol{S T E M}$ field was caused by strong sentiment of male domination and gender stereotypes upon pursuing for career [35]. The data showed that women's high participation in education was not supported by their capacity to make critical decision and opted to enter STEM field due to its masculine stereotype.

Based on the problem presented above, how does the curriculum at HE serve as a substantial instrument in the formation of critical thinking, technical capacity, and the ability to decide in substantial participation without the constraints of gender construction? This strategy should be in the level of higher education policy in determining the importance of GESI. GESI perspectives from policy makers are needed in HE system, which was still dominated by men. Since 2010 , Indonesia only had $8^{4}$ female Rectors $(0.2 \%)$ out of the total 4,621

\footnotetext{
${ }^{3}$ In 2018 and 2019 at six Higher Education institutions and two Association Meetings.

${ }^{4}$ Prof. Dr. Hj Badia Perizade, MBA., Rector of Universitas Sriwijaya (Unsri); Prof. Ir. Tian Belawati, M.Ed., Ph.D. Rektor of Universitas Terbuka; Risa Santoso, BA., MA. Ed, Rector of Institut Teknologi Bisnis Asia Malang; Reini Wirahadikusumah., Rector of Institut Teknologi Bandung (ITB); Prof Dr Amany Burhanudin Umar Lubis Lc MA., Rector of
} 
Rectors in Indonesia. Such number as considered low, but the movement and efforts to realize this number was an achievement on its own. In general, women's leadership in the directorate, faculty, and its supporting units was still relatively lacking. Whereas, the position of women in study programs increased each year. Therefore, the challenges of GESI in higher education was not only limited to low representation of women's leadership, but also lack implementation of GESI perspective from female agents. These factors slowed the change of campus systems and structures to be more gender equitable and socially inclusive. It took strategic and active role of lecturers, leaders at the faculty/study program level, and study centers to integrate GESI in education and teaching activities, research and community service projects, and publications. Table 2 below provided an overview of lecturers in Higher Education. The resources available for lecturers in HE was also shown in the following table.

Table 2. The Lecturer Profiles in Higher Education According to Gender

\begin{tabular}{|l|c|c|c|c|c|c|c|c|c|c|}
\hline Lecturer & \multicolumn{10}{|c|}{ Tahun } \\
\hline Gender & 2015 & $\%$ & 2016 & $\%$ & 2017 & $\%$ & 2018 & $\%$ & 2019 & $\%$ \\
\hline Man & 118,801 & $57 \%$ & 129,151 & $57 \%$ & 137,525 & $57 \%$ & 145,044 & $55 \%$ & 166,979 & $56 \%$ \\
\hline Female & 88,010 & $43 \%$ & 98,583 & $43 \%$ & 105,312 & $43 \%$ & 116,783 & $45 \%$ & 129,061 & $44 \%$ \\
\hline Total & 206,811 & $100 \%$ & 227,734 & $100 \%$ & 242,837 & $100 \%$ & 261,827 & $100 \%$ & 296,040 & $\underline{100 \%}$ \\
\hline
\end{tabular}

Source: Pusdatin Diktatin Dikti in 2017 and PPDikti data in 2019

The data acquired from Data and Information Publication of DIKTI [33], [36] on Table 2 above showed that in the last five years, the percentage of male lecturers was still higher than female lecturers and the difference was $13 \%$ on average. The number of female lecturers continued to increase annually and in 2019 it reached $44 \%$ of the number of lecturers in Indonesia. Even though it was still below the percentage of male lecturers, this percentage was relatively good because it was above the $30 \%$ quota, which became the commitment of women's representation in various aspects, including education. It was hoped that with at least $30 \%$ representation, there would be a space for women to make an impact through responsive gender critical education through its role in education and pursuits, research and community service projects, and publication of works. However, the trend in the number of female lecturers above did not guarantee that they had "more" sensitivity and capacity related to GESI and integrate in their activities.

Educational policy in Law No. 2 of 2003 emphasized the importance of curriculum in education and teaching to achieve educational goals. In the context of GESI, the method to include GESI in the curriculum and syllabus became important. Based on the secondary data, there had been no available macro data within higher education to see the lists of explicitly-related GESI subjects included as its independent or optional course. Similarly, there was no lists of compulsory or optional courses integrated with GESI perspective. However, based on the FGD and in-depth interview in HE institutions, which served as the subjects of this study, we found an overview of how gender/GESI theme was included in the higher education system and activities. The findings were described below:

First, there was no specific policy in education and teaching regarding the implementation of GESI at HE level. However, the implementation of GESI could be separately found in the documents of the implementation of education and teaching at the faculty/study program level. For example in the opening of women's and gender study programs at post-graduate level in three state universities (Universitas Indonesia, Universitas Brawijaya, and Universitas Hasanuddin). Women's Study Master Program at Universitas Indonesia (UI) was the first postgraduate women's study program in Indonesia, which was officially founded in November 1990, while the other two similar programs were founded in 2009 or 13 years after the initiation by UI. Other document explaining the implementation of GESI was described in the Rector Decree related to the courses presented at the department/faculty level. The submission process depended on the grass root level or from the group of lecturers/study programs through the studies as a rationale for opening courses and subjects related to GESI. Therefore, the role of lecturer/instructor as a critical agent both personally and in groups became an important aspect in establishing dialogue spaces to influence policymakers to include more GESI-related courses or integrate GESI in the existing courses.

UIN Syarif Hidayatullah Jakarta; Prof. Dr. Rina Indiastuti, M.SIE., Rector of Universitas Padjadjaran (UNPAD); Prof. Dr. Dwia Aries Tina Pulubuhu, MA., Rector of Universitas Hasanuddin; and Prof. Dr. Ir. Ellen Joan Kumaat, M.Sc., DEA., Rector of Universitas Sam Ratulangi Manado 
Based on the previously-conducted FGD ${ }^{5}$ with lecturers, we found that almost all lecturers who taught these courses had experience and critical knowledge related to GESI. Among these experiences, we could conclude several major points: 1) they were alumni of women's and gender study Master's Degree programs from Indonesia and/or overseas, 2) during their study, they were inspired to further concentrate on the study field, 3) they were involved as an assistant of a senior lecturer who taught the course, 4) they were involved in joint research with other colleagues who had paid attention gender and social inclusion issues, and 5) the interest came from their personal experience of living in a highly patriarchal society where violence against women and girls becomes a daily routine.

Second, GESI as an independent subject was included in study program at Master's and Doctorate Degree. There were three state universities offering women's and gender study programs, which included Universitas Indonesia (Gender Studies), Universitas Hasanuddin (Gender and Development), and Universitas Brawijaya (Women Studies study program). On these programs, GESI became the main topic and was integrated in all courses. However, in the last 10 years, these study programs received lack of attention and interest, as seen through small number of students enrolling in the program. The policies and commitment to continue the study program was a positive endeavor, but at the same time, it became a dilemma amidst the attempt to industrialize HE, which focused more on economic considerations.

Third, GESI as independent course was included on study programs and faculties at undergraduate and postgraduate programs. Most of these courses were in social studies programs/faculties such as sociology, anthropology, communication, law, education, politics, language and literature, family, and public health. The course name was adjusted based on the focus of its study program, for example gender sociology, gender and feminism, gender anthropology, women and literature, gender and politics, gender and law, gender and development, gender and family, gender and reproductive health, and gender and communication. In the overall course structure, there were one or two subjects with GESI topics ( 3 to 6 credits) per study program or around 2.5-5\% of the total credits at social sciences study programs. Courses on GESI was presented as a compulsory and/or optional independent course, which could be openly enrolled by students from other study programs/faculties. One interesting example, at a certain private university, Gender and Feminism course was a compulsory course in a faculty and could be chosen as an optional course in other faculties. In the implementation, there were students from the Faculty of Electrical Engineering, Faculty of Informatics, Public Health, and others who took interest and enrolled for the course. There were also other circumstances in which some study programs offering courses on gender and it became an optional course of another study program/faculty at a university.

Fourth, GESI as a complementary topic of subject and it was integrated with courses at the faculty of social sciences, both in undergraduate and postgraduate programs. GESI became a part of topic in the existing courses, and structurally, it was included in one or two class sessions or at least 7-14\% of a course. Upon observing the structure of the course, GESI topics could be positively included in all sessions of the course. For example, in Classic Sociology Theory, GESI could also be included in the course because it could be implemented in the methodology, on thematic student study service, and final project in the form of final paper, thesis, or dissertation. It could be concluded that it was possible to implement GESI in several topics. Even though it would be difficult to precisely measure the compatibility because the conditions of each study program were different, based on the FGD we conducted, it could be estimated that around 10-15\% of GESI issues could be included in various courses at study program or faculty level.

Fifth, GESI served as a complementary topic but was included in the subject matter of compulsory general courses at university level. Generally, there were 4 general courses namely Indonesian Language, Pancasila, Citizenship, and religion. GESI topics could be included in these general courses and it would depend on whether or not the lecturer had the capability, perspective, conceptual ability, and methods to integrate them in these courses. If the lecturer could include GESI issues on each course ( 8 credits), for example in one or two class sessions, it could be estimated (qualitatively) that $10 \%$ of GESI issues were included in the general course.

Sixth, GESI was included in learning and assignment method. It was revealed in the FGD that if GESI issues could not be included in teaching materials, teachers could employ creative method by GESI issues in learning and assignment method through case selection related to women's, gender, family, or people with disability issues. Usually this strategy was implemented by our colleagues who teach hard sciences, for example mathematics, biology, physics, electro, agriculture, and so on. Sensitivity and teaching skills were acquired through a process of collaborative research with social partners focusing on these issues. For example,

\footnotetext{
${ }^{5}$ FGD was conducted with 6 universities and 2 associations
} 
developing natural coloring for female community, developing food diversity for female community, developing alternative energy, and other aspects that were close to marginal communities.

Seventh, GESI Capacity Building. There were few teachers with background in the field of women's, gender, and feminist studies and social inclusion both at undergraduate and postgraduate level. Hence, most teachers developed their conceptual abilities, methodology, and praxis independently through several sources, including literature, journals, training, workshops, seminars, short lectures, and by joining the Center for Women's and Gender Studies and other networks. However, the opportunity for knowledge improvement was not coordinated properly and sustainably. By the account of several seniors in women's and gender studies ${ }^{6}$, one program that was mostly unforgettable was a three-month short course at a European university as the organizer. This program was conducted by the collaboration of the Ministry of Women's Roles Affairs, the Ministry of Education and Culture, and several European universities who were experts on the topic. The program recruited several lecturers at the university who were prepared to become focal points at the university, the government, and the community related to GESI issues. Some of the program alumni still actively participated as experts in GESI field in Indonesia. Another interesting point, many of them were women. Male feminists seemed to be extremely rare in Higher Education. A male lecturer who taught women's and gender studies was seen as peculiar. Someone once asked him jokingly, "Sir, are you okay? Still a man, aren't you?"

Eighth, most of the instructors in this course already focused on GESI issue for a relatively long-term concern as seen through their contribution in research and community service projects, and publications. They also actively participated in networking and engaging in groups and/or organizations related to women, gender, people with disability, and other related social identities. However, GESI issue had not been directed to be a continuous research roadmap. There were still some teachers who remained inactive at both on-campus and offcampus centers for women's/ gender/family/people with disability, which served as a place to discuss conceptual, methodological, and praxis ideas, which would be further developed to viable courses. This could be seen as the fact that education and teaching were not based on the results of research and community service projects. Furthermore, Study Centers for women's/gender/family/people with disability were not yet utilized as a reference or basis for the development of teaching materials.

During the FGD, there was a dialogue to try to qualitatively measure the percentage of GESI issues that could be integrated in teaching and education process of a study program/faculty at higher education level. The discussion revealed that there was around 10-30\% opportunity depending on the condition of the university. For example, a university with strong scientific development towards science, engineering, engineering, mathematics (STEM) or hardware had $10 \%$ chance. On the other hand, at universities focusing more on social sciences or universities in which its technology development focusing on social issues would have $20-30 \%$ chance of integrating GESI issues. However, such qualitative estimate certainly could not be generalized. In the context of this case study, it could provide an idea to the insufficiency of methods in implementing GESI in education and teaching. This argument was based on discussions during the FGD that the syllabus of courses related to GESI issues had not been properly evaluated. Furthermore, there was a need to compile a guideline that would become a common reference for standard issues and issues to be developed based on the specific context of each study program, faculty, or university.

Based on the testimony of most teachers, GESI was not a popular topic on campus. There were not many lecturers who were interested in this topic because it was considered as unusual, non-mainstream, and the tendency to create extremely critical and 'disapproving' groups. On the other hand, based on the in-depth interview conducted to the dean and chair of the study program, it was revealed that initiating and maintaining the course was not an easy feat. It took hard work, formal and informal discussion in meetings at the level of faculty and study program. They recounted that it was important to establish a negotiation space where one could provide proper comprehension and concrete evidence on the importance of implementing GESI issues.

\subsubsection{GESI Institutionalization in Higher Education: Study Center for Women/Gender?}

The management of research and community service projects for HE in Indonesia is regulated under the Regulation of the Ministry of Research, Technology and Higher Education No. 44 of 2015 and the Amendment of Regulation of the Ministry of Research, Technology and Higher Education No. 50 of 2018, National Standards of Higher Education (Standar Nasional Pendidikan Tinggi/SN Dikti) in research and community service projects. It is also mentioned in the Regulation of the Ministry of Research, Technology and Higher Education No. 24 of 2019 on the Management of Higher Education Innovations. Furthermore, this policy becomes a policy umbrella for operational guidelines in providing access for lecturers and researchers in HE to access funds and participate in research and community service projects.

\footnotetext{
${ }^{6}$ In-depth interview
} 
Until 2015, the Ministry of Research, Technology, and Higher Education of Republic of Indonesia had not accommodate GESI-related issues within the operational documents containing the guidelines for research and community service projects. This affected on lower opportunities for GESI-related research and community service projects to be approved and to acquire funding and publication. Sayogja Institute's study found that there was only $2 \%$ of GESI-related research funded by the Ministry of Research, Technology and Higher Education in 2013-2015. The Director of Research and Services revealed that the gap between the number of female and male researchers was relatively low compared to other countries. This showed that women had enough opportunity to be active in research. However, female researchers were mostly concentrated in several leading universities in Indonesia. Of the 3,246 universities in Indonesia, only 25 universities (1\%) had the highest quality category, 76 (2\%) universities were included in the second category, and the remaining 3,145 universities (97\%) were in the low category. We can conclude that women's opportunities remained a challenge in terms of distribution in other universities [37].

By considering this issue, the Ministry initiated discussions, seminar, and FGDs between institutions since 2016. This was a collaboration effort with the Ministry of Women Empowerment and Child Protection, DRPM Kemenristekdikti, KSI, Asosiasi Pusat Studi Wanita/Gender \& Anak se Indonesia, and it had produced significant changes. DRPM Kemenristekdikti through Presidential Regulation No. 38 of 2018 on the National Research Master Plan (Rencana Induk Riset Nasional/RIRN), more specifically in Guideline XII which included GESI issues by adding relevant themes and topics for each focus area of national research priority (integrated). The next step was to recruit national reviewers for GESI expertise, conducted a series of capacity building for national reviewers to have an understanding and perspective on GESI issues, and organized workshops to write gender responsive proposals for lecturers in several locations. This policy provided more open access for female researchers and GESI-related research to obtain funding from the Ministry. The explanation below would describe women's access and the implementation of GESI topics in research and community service projects from HE under Kemenristekdikti.

Structurally, research in Higher Education through study program/faculty becomes one of the lecturers' responsibilities, which is conducted personally, with study groups, or through study centers at the university level. Study centers are established by the Decree of Rector for both its establishment and management. In some study centers, the chairpersons or core administrators are determined by the Board of Directors in the university level. By considering this, if the university appoints a personnel who has no or lack of experience in the field of GESI, the center will suffer from lack of activity and it will become passive. This issue emerges due to the fact that the former members are usually no longer involved in the management, which will affect the organization itself in terms of program sustainability. Unlike other universities, it will be better if the study center is the one which proposes the change of management, including its chairperson.

In general, researchers at study centers come from various study programs/faculties at the university. Therefore, a lecturer is allowed to join two or three different study centers. The center for women's and gender studies is commonly organized under the university with various names, for example center for women's study, center for gender study, center for gender and children study, center for gender and family study, and so on. Since the study center is at a study program/faculty level, it does not have full time researchers. It also has less active administrators, maybe three to five people. When there is a research program, there will be more participants because the involvement of other members depends on the program. In addition, most lecturers, especially in private universities, have higher teaching load, which influence the time they could spend on research.

Based on the FGD, we obtained several important findings about the participation in a study center. The findings included: 1) most of them were alumni of women's and gender study Master's Degree programs from Indonesia and/or overseas, 2) during their study, they were inspired to further concentrate on the study field, 3) they were involved as an assistant of a senior lecturer who taught the course, 4) they were involved in joint research with other colleagues who had paid attention gender and social inclusion issues, and 5) the interest came from their personal experience of living in a highly patriarchal society where violence against women and girls becomes a daily routine. Their strong interest and commitment influenced the variation of programs and sustainability of the study center. Center for women's and gender study actually has different characteristics compared to other study centers. These centers commonly not only focusing on the conceptual aspects (feminist theory) and publish scientific work products, but also in practical terms by providing liberating solution for the research subjects, which mainly comprise of women, children, and other marginalized groups. In conclusion, these study centers do not only require conceptual abilities but also consistency and commitment in the movement (especially feminist movement) of concrete changes focusing on the unjust systems and societal structures to a group of people.

Upon studying the internal management of HE institutions, we found several facts. First, the support for institutionalizing GESI in Higher Education was still weak. This was a conclusion based on the facts that: (1) out 
of 72 higher education institutions completing GESI survey, a majority (46\%) did not have a center for women's and gender study, while the rest of them (43\%) already had the study center, and $11 \%$ of GESI-related research were also conducted at other study centers. This also meant that the position of this institution determined the effort to integrate GESI in research and community service projects. It was also revealed that the institutionalization of center for women's and gender study in the last two and three experienced a decline in status from being independent to a sub-topic by merging with other study centers. Furthermore, the management of these study centers was proven to be rather weak and less sustainable, and they had a strong base in the faculty/study program. Most of these study centers only had its chairman by the Decree of Rector. Therefore, the strength and sustainability of these study centers would be highly dependent on the chairperson's managerial and leadership abilities. Few of these study centers had relatively more complete management structure as proposed and appointed by the university decree. (2) Most lecturers and researchers involved in the study centers were female. Their interest in GESI-related research began to escalate, but there were still some issues such as their lack of capacity in GESI-related research. GESI studies are actually interdisciplinary, but most of the research was dominated by social-humanities science. (3) Most of these study centers did not receive regular funding support from the University for research and community service projects. This also meant that the funding for research and community service projects activities relies more on off-campus funding, for example through Kemenristekdikti and other domestic sources. One source of funds that was widely used by these study centers was through cooperation with the Regional Government, which was commonly short term and not sustainable.

All centers for women's and gender study had its formality basis in the form of the Rector Decree. However, it could be further found in documents as a reference for the development of research and community service projects, for example the strategic plans for higher education, master plans for research and community service projects, and master plans for study programs/faculties. Most of these documents had not explicitly include GESI as one of the focus of research and community service projects. This evidence showed that GESI had not become a serious concern and an integral part of the university. Therefore, the existence of these study centers experienced instability from year to year. In the history of Indonesia, there was a time where the center for women's and gender study was required by the New Order Government, especially in Higher Education in the 1980s based on the policy that responded to the global women's movement by limiting such movement through various women's organizations, including study center for woman. Some studies highlighted this movement as an effort to subdue women or "Ibuisme" (motherhood) movement [38].

As explained above, the education and teaching activities were not based on the results of research and community service projects. Some of the lecturers who taught GESI-related courses were not affiliated to the center of women's and gender study. Therefore, the study center itself had not collaborated with the study program. Only a few lecturers and researchers integrated GESI based on the results of research and community service projects in classroom learning. The findings of research and community service projects could enrich the empirical understanding of students and inspire them to further conduct research and community service projects.

Based on the data collected by Asosiasi Pusat Studi Wanita/Gender \& Anak se Indonesia (ASWGI), there were 143 centers for women's and gender study in Indonesia, which scattered in state, private, and religionbased HE institutions under the Ministry of Religion in 2016. This meant that there were actually 4\% of 3,246 HE had their own center of women's and gender studies. Out of these 143 study centers, 59 (41\%) were active and the remaining $84(59 \%)$ were in development. Table 3 provided detailed information on this information. In 2019, a number of centers for women's and gender studies were closed or merged with other study centers because they were considered as inactive, unable to finance their activities, and as the result of university management changes in research procedures for efficiency reasons. Most of these study centers did not obtain funding support from the university, and the sustainability of these study centers highly depended on their ability to raise external funds through various research and community service projects opportunities. However, some study centers, especially in state universities, received small funding allocations from the university.

Tabel 3. Number of The Center for Women's/Gender Studies

\begin{tabular}{|r|l|c|c|c|}
\hline \multirow{2}{*}{ No } & \multicolumn{1}{|c|}{ Types of University } & \multicolumn{2}{c|}{ Category } & Total \\
\cline { 3 - 5 } & & Established & Developing & \\
\hline 1 & Public University & 30 & 25 & 55 \\
\hline 2 & Private University & 12 & 33 & 45 \\
\hline 3 & University under Ministry of Religious Affairs & 13 & 26 & 40 \\
\hline 4 & Master's programs in Gender Studies & 3 & 0 & 3 \\
\hline & & 56 & 84 & 143 \\
\hline
\end{tabular}


Sumber: ASWGI $^{7}$, tahun 2017

Based on the conducted FGD and the secondary data acquired from the National Coordination Meeting of ASWGI in 2015-2018, there was an interest and development of the Center for Women's, Gender, and Children Studies in several universities. The issues of gender-based violence and other forms of social violence were mainly caused by lack of knowledge, skills, innovation and technology, and policies that would concretely address poverty in society, and it was further buttressed by the constraints of strong patriarchal values and norms in some communities.

Therefore, we needed an active role of researchers and lecturers to participate in this issue. Research and community service projects came from a proper understanding of GESI issues and would generate right solution to this problem. In a series of FGDs and National Coordination Meeting, we had formulated and taken strategic steps, including 1) GESI perspective methodology workshop, 2) workshop for writing proposals with GESI perspective, 3) writing workshop for results of research and community service projects, 4) workshop to implement GESI perspective in curriculum, and 5) actively conducting communication and dialogue with the Ministry in order to generate more opportunity and affirmative policy for involving women in GESI research independently and/or integrate GESI with the existing schemes.

In the midst of the lack of GESI integration in HE, 143 institutions had established centers for women's, gender, and children studies. They formally formed an association - called ASWGI - in 2015. Collaborating with Forum Rektor Indonesia, ASWGI recommended the implementation of GESI in HE and to organize workshops to develop gender-oriented curriculum, research proposals, and article writing. The findings showed that around $60 \%$ of 146 study centers had integrated GESI into teaching and education. Around 30\% had integrated GESI into the master plan for research and community outreach programs, and training for proposals and paper writing. In addition, around $60 \%$ had actively submitted proposals with GESI perspective to the Ministry of Research, Technology, and Higher Education.

\subsubsection{GESI in Research and Community service programs}

Based on the previous overview of research institutions and center for women's and gender study in HE, it was interesting to see how various topics of research and community service projects topics received attention and access to funding from Kemenristekdikti, especially after 2015 after a change of policy that affirmatively included GESI in Guideline XI (2018), which was then perfected as Guideline XII in 2019.

Education Sector Analytical and Capacity Development Partnership (ACDP) [39] reported that a research conducted by Sajogyo Institute, which compiled the data from Kemenristekdikti, showed that $30 \%$ female researchers had access to research funding annually in 2013-2015. It was further explained that only $3 \%$ of the funded research was related to gender and women's issues in 2013. This percentage dropped to $2 \%$ out of more than 12,000 research projects funded in 2014 and 2015 [39]

From the results of data analysis taken from Kemenristekdikti in 2013-2017 [37], the trend of funding for research continued to increase every year. Based on the findings, there were 73,695 funded research titles covering all schemes. Of the total research funded titles, only 5,182 (7\%) were related to GESI and the remaining titles were non-GESI projects. Upon further examination, out of the 5,182 GESI-related research, the subjects were women/gender $(2.7 \%)$, children and children with special needs $(2.4 \%)$, people with disability $(0.3 \%)$, elderly $(0.2 \%)$, and farmers \& fishermen $(1.4 \%)$. The subjects of this study were mainly the marginalized communities.

Table 4. The Title of Research Funded by Kemenristekdikti

\footnotetext{
${ }^{7}$ Indonesian Association of Women and Gender Studies
} 


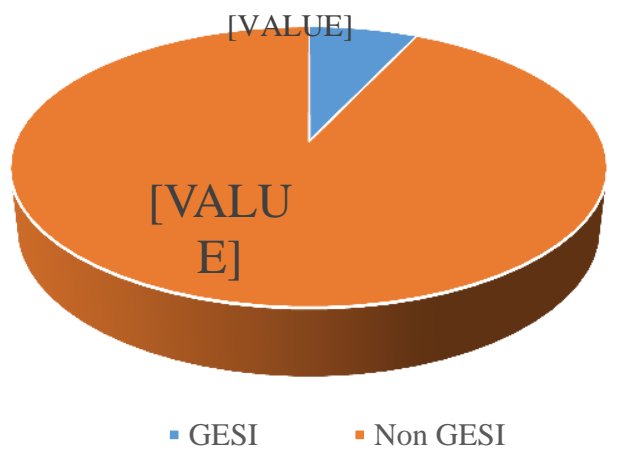

Table 4 showed that the number of GESI-funded research titles remained small, but this number had increased to $7 \%$ compared to 2013-2015, which only comprised of $2 \%$ of the total funded research. This increase was inseparable from the Ministry regulation to encourage the implementation of GESI in research grants, which was conducted since 2015. The occurring increase, even though it was relatively, continued to climb steadily. The policy was in line with the Ministry policy to 1) recruit and train female researchers with gender perspective to become national reviewers on competitive and decentralized grants, 2) involve researchers with gender perspective in the revision and preparation of the Guidelines XI, 3) include GESI in all available schemes in Guidelines XII, 4) organize workshops for preparing a GESI perspective proposal, and 5) provide access to women to be involved in every program, both related to the preparation of proposals, reviewers, writing research output, and policy formulation.

Upon examining the number of funded projects by Kemenristekdikti in 2013-2017 based on its GESIrelated theme and gender factor, there were 32,313 research titles supervised by women (44\%) and 42,382 titles $(56 \%)$ supervised by men. When the data were compared based on the gender of funding recipients, it was obvious that the total number of female researchers receiving funds was still lower than men. From Table 5 below, it appeared that most of GESI-related research were supervised by women (2,981 titles) if compared to men (2,201 titles). This promising potential could be the power of female lecturers in producing more research related to gender or GESI issues.

Table 5. The Title of Research Funded by Kemenristekdikti According to GESI \& Non GESI \& Gender Themes, 2013-2017

\begin{tabular}{|c|c|c|c|c|c|c|}
\hline \multirow{2}{*}{ Gender } & \multicolumn{7}{|c|}{ The Title of Research } \\
\cline { 2 - 7 } & GESI & $\%$ & $\begin{array}{c}\text { NON } \\
\text { GESI }\end{array}$ & $\%$ & TOTAL & $\%$ \\
\hline Women & 2,981 & $4 \%$ & 29,332 & $40 \%$ & 32,313 & $44 \%$ \\
\hline Man & 2,201 & $3 \%$ & 39,181 & $53 \%$ & 41,382 & $56 \%$ \\
\hline & 5,182 & $7 \%$ & 68,513 & $93 \%$ & 73,695 & $100 \%$ \\
\hline
\end{tabular}

Resource: Kemenristekdikti, 2018

An interesting question is, what are the most common GESI-related research titles? Table 5 showed that most of them were on agriculture or food. They also included social aspects such as education. However, upon further study based on gender, most men preferred agriculture and women focused more on social aspects. It was quite interesting to see that there were also other fields of study including information technology, games, films, applied technology, and social media.

Table 5. Title of GESI Research by Field \& Gender

\begin{tabular}{|c|c|c|c|c|c|c|}
\hline \multirow{2}{*}{ GESI in the Field } & \multicolumn{7}{|c|}{ The Research Title in 2013-2017 } \\
\cline { 2 - 7 } & Man & $\%$ & Female & $\%$ & Total & $\%$ \\
\hline Agriculture & $\mathbf{5 0 2}$ & $\mathbf{2 2 . 8 \%}$ & $\mathbf{4 2 1}$ & $\mathbf{1 4 . 1 \%}$ & 923 & $17.8 \%$ \\
\hline Food security & 35 & $1.6 \%$ & 65 & $2.2 \%$ & 100 & $1.9 \%$ \\
\hline
\end{tabular}




\begin{tabular}{|c|c|c|c|c|c|c|} 
The economy & 114 & $5.2 \%$ & 144 & $4.8 \%$ & 258 & $5.0 \%$ \\
\hline Health & 102 & $4.6 \%$ & 233 & $7.8 \%$ & 335 & $6.5 \%$ \\
\hline Social & $\mathbf{6 4 9}$ & $\mathbf{2 9 . 5 \%}$ & $\mathbf{1 0 2 8}$ & $\mathbf{3 4 . 5 \%}$ & $\mathbf{1 6 7 7}$ & $\mathbf{3 2 . 4 \%}$ \\
\hline Poverty & 85 & $3.9 \%$ & 87 & $2.9 \%$ & 172 & $3.3 \%$ \\
\hline Political & 124 & $5.6 \%$ & 191 & $6.4 \%$ & 315 & $6.1 \%$ \\
\hline Environment & 44 & $2.0 \%$ & 58 & $1.9 \%$ & 102 & $2.0 \%$ \\
\hline Natural resources & 20 & $0.9 \%$ & 11 & $0.4 \%$ & 31 & $0.6 \%$ \\
\hline Other & 526 & $23.9 \%$ & 743 & $24.9 \%$ & 1269 & $24.5 \%$ \\
\hline Tota & 2201 & $100.0 \%$ & 2981 & $100.0 \%$ & 5182 & $100.0 \%$ \\
\hline
\end{tabular}

Source: Analysis of Secondary Data of Kemenristikdikti, 2013-2017

Related to community service projects, the results of data analysis were the title of community service projects funded by Kemenristekdikti from 2013-2017. Out of 13,051 titles funded, there were 1,497 titles (11\%) related to GESI and 11,554 titles (89\%) were non-GESI topics. An interesting finding was that the funded community service projects by male researchers was slightly higher than women.

Table 6. Title of Community Service Funded by Kemenristekdikti According to GESI and Non GESI, 2013-2017

\begin{tabular}{|l|c|c|c|c|c|c|}
\hline \multirow{2}{*}{ Topik } & \multicolumn{6}{|c|}{ Tahun $2013-2017$} \\
\cline { 2 - 7 } & Man & $\%$ & Female & $\%$ & Total & $\%$ \\
\hline GESI & 712 & $13 \%$ & 785 & $11 \%$ & 1,497 & $11 \%$ \\
\hline NON GESI & 4,968 & $87 \%$ & 6,586 & $89 \%$ & 11,554 & $89 \%$ \\
\hline Total & 5,680 & $100 \%$ & 7,371 & $100 \%$ & 13,051 & $100 \%$ \\
\hline
\end{tabular}

Source: Analysis of Secondary Data of Kemenristikdikti, 2013-2017

In general, the number of funded community service projects titles was even lower at $15 \%$ (13,051 titles) compared to $75 \%$ of research funded titles $(73,695$ titles) of the funded research and community service projects. Based on this number, it seemed that community service projects as a part of the implementation of research results in the community was not yet a concern. Furthermore, even though the number of GESI-related research continued to increase, the number of funded research (7\%) and community service projects (11\%) remained low. GESI perspective was relevant to be included in all research because they focused on people with diverse problems and needs as its research subjects. However, most research and community service projects were neutral and some of them were gender biased.

From the data presented above, research related to GESI was still relatively scarce. There were some problems affecting this, which included: 1) GESI was not clearly stated as a national research priority, 2) lack of knowledge and/or skills in integrating GESI into any existing scheme, 3) limited number of proposal reviewers who were experts at GESI, and 4) the existing patriarchal norms. Even though GESI had strong foundation in the government policies, it was not yet an integrated part of the implemented state policy such as the National Development Plan. Accordingly, HE had not fully committed to integrate GESI into management and the three obligations of higher education institutions (education, research, and community service projects). However, even though the numbers were relatively small, there were movements at grass root level from lecturers and researchers who already had integrated GESI perspective in the higher education system. Through their individual and group effort and by joining the study center, they continued to integrate GESI issues in education, teaching, research, community service projects and publication.

\section{Conclusion}


GESI has a strong basis in government policy but not yet an integrated part of the state policy implementation such as the National Development Plan. In line with that the higher education has not yet fully commitment to integrate GESI into management and the three higher education's obligations (education, research, and community services). Even though the numbers are relatively small, there is a movement from the 'bottom' from the lecturers / researchers who already have a GESI perspective.

The Weak Gong the GESI Mainstreaming in Higher Education appears, among others; 1) institutional support and funding; 2) The capacity of lecturers and researchers related to GESI both concepts, methodology, and praxis; 3) The GESI has not been explicitly included in the Tri Darma Higher Education strategic plan.

Maistreaming GESI in Higher Education through the Gender Equality-Justice \& Social Inclusion Model in the Field of Research and Community Service in Universities requires synergy of four components, including; a) GESI sorting data; b) Higher Education commitment in the form of policy support for integrating GESI explicitly in the Tri Darma in Higher Education strategic plan; c) strong GESI institutions and internal funding support for Higher Education; d) human resources who has a GESI expert; d) Implementation of GESI in Tri Darma in Higher Education sector; and e) Publication and advocacy for sustainability.

\section{References}

[1] Wahid Institute, "Laporan tahunan kebebasan beragama / berkeyakinan dan intoleransi 2014: 'Utang' warisan pemerintah baru," Jakarta, 2015. [Online]. Available: http://wahidinstitute.org/wi$\mathrm{id} /$ images/upload/dokumen/laporan kbb 2014 - the wahid institute.pdf.

[2] United Nations Development Programme, "Human development indices and indcators: 2018 statistical update," New York, NY, 2018. [Online]. Available: http://hdr.undp.org/sites/default/files/2018_human_development_statistical_update.pdf.

[3] Organisation for Economic Co-Operation and Development, "Good jobs for all in a changing world of work: The new OECD jobs strategy - Key findings for Indonesia," 2018. [Online]. Available: https://www.oecd.org/indonesia/jobs-strategy-INDONESIA-EN.pdf.

[4] United Nations Development Programme, "Human development report 2016: Human development for everyone," New York, NY, 2017. [Online]. Available: http://hdr.undp.org/sites/default/files/2016_human_development_report.pdf.

[5] United Nations Development Programme, "Human development report 2015: Work for human development," New York, NY, 2016. [Online]. Available: http://hdr.undp.org/sites/default/files/2015_human_development_report_0.pdf.

[6] Ministry of Environment and Forestry Republic of Indonesia, "Indonesia report on REDD+ performance," Jakarta, 2018. [Online]. Available: http://ditjenppi.menlhk.go.id/reddplus/images/adminppi/dokumen/Book_IRPR_KLHK_B5_revisi_4_opt.pdf.

[7] A. Hsu et al., The 2014 environmental performance index. New Haven, CT: Yale Center for Environmental Law \& Policy, 2014.

[8] C. West and D. H. Zimmerman, "Doing gender," Gend. Soc., vol. 1, no. 2, pp. 125-151, 1987, doi: https://doi.org/10.1177/0891243287001002002.

[9] J. Butler, "Gender trouble, feminist theory, and psychoanalytic discourse," in Feminism/postmodernism, L. J. Nicholson, Ed. New York: Routledge, 1990, pp. 324-340.

[10] S. Walby, Theorizing patriarchy. Oxford: Basil Blackwell, 1990.

[11] United Nations, "Progress of the world's women 2002, volume 2: Gender equality and the millennium development goals," New York, NY, 2002.

[12] United Nations, United Nations Women: Annual Report. New York, NY: United Nations, 2017.

[13] A. Walker and C. Walker, Britain divided: The growth of social exclusion in the 1980s and 1990s. London, UK: CPAG, 1997.

[14] A. de Haan, "Social exclusion: An alternative concept for the study of deprivation?," Inst. Dev. Stud. Bull., vol. 29, no. 1, pp. 10-19, 1998.

[15] R. Alsop, M. Bertelsen, and J. Holland, Empowerment in practice: From analysis to implementation. Washington, DC: The World Bank, 2006.

[16] United Nations, “Achieving gender equality, women's empowerment and strengthening development cooperation," New York, NY, 2010.

[17] International Development Partners Group, A common framework for gender equality and social inclusion. Nepal: 
International Development Partners Group, 2017.

[18] Australian Aid, “Australia-Indonesia partnership for pro-poor policy: The knowledge sector initiative," Canberra, 2018. [Online]. Available: https://www.dfat.gov.au/sites/default/files/indo-ks-design.pdf.

[19] C. D. Aruan, "Sumber daya manusia dan gender pada pendidikan tinggi Indonesia," Jakarta, 2018.

[20] E. Cahyono, C. Larastiti, B. Zaini, U. Latifah, and I. Maulana, "Keadilan gender dan inklusi sosial dalam hibah penelitian kementerian riset, teknologi, dan pendidikan tinggi 2013-2015,” Jakarta, 2017.

[21] K. Nugroho, F. Carden, and H. Antlov, "Pentingnya pengetahuan lokal! Kekuasaan, konteks, dan pembuatan kebijakan di Indonesia," Jakarta, 2018.

[22] United Nations Educational Scientific and Cultural Organization, "Gender issues in higher education: Advocacy bief," Bangkok, 2010.

[23] Komnas Perempuan, "Kekerasan meningkat: Kebijakan penghapusan kekerasan seksual untuk membangun ruang aman bagi perempuan dan anak perempuan, catatan KTP 2019," Jakarta, 2020. [Online]. Available: https://www.komnasperempuan.go.id/file/pdf_file/2020/Catatan Tahunan Kekerasan Terhadap Perempuan 2020.pdf.

[24] United Nations Development Programme, "Beyond income, beyond averages, beyond today: Inequalities in human development in the 21st century," New York, NY, 2019. [Online]. Available: http://hdr.undp.org/sites/default/files/hdr2019.pdf.

[25] Ministry of Women's Empowerment and Child Protection Republic of Indonesia, Pembangunan manusia berbasis gender. Jakarta: Ministry of Women's Empowerment and Child Protection Republic of Indonesia, 2019.

[26] World Economic Forum, “Global gender gap report,” Geneva, Switzerland, 2020. [Online]. Available: http://www3.weforum.org/docs/WEF_GGGR_2020.pdf.

[27] Z. A. Wendling, J. W. Emerson, D. C. Esty, M. A. Levy, and A. de Sherbinin, "2018 environmental performance index report," New Haven, CT, 2018. [Online]. Available: https://epi.envirocenter.yale.edu/downloads/epi2018reportv06191901.pdf.

[28] Ministry of Education and Culture Republic of Indonesia, "Gender equality in education in Indonesia," Jakarta, 2018.

[29] Komnas Perempuan, "Tergerusnya ruang aman perempuan dalam pusaran politik populisme, catatan KTP 2017," Jakarta, 2018. [Online]. Available: https://www.komnasperempuan.go.id/file/pdf_file/2018/Publikasi/Catatan Tahunan Kekerasan Terhadap Perempuan 2018.pdf.

[30] Yayasan LBH APIK, "Catatan tahunan LBH APIK Jakarta berdasarkan pengalaman penanganan kasus dan advokasi tahun 2018," Jakarta, 2019.

[31] Komnas Perempuan, "Kekerasan terhadap perempuan meluas: Negara urgen hadir hentikan kekerasan terhadap perempuan di ranah domestik, komunitas dan negara, catatan KTP tahun 2015,” Jakarta, 2016. [Online]. Available: https://www.komnasperempuan.go.id/file/pdf_file/Catatan Tahunan/14.PP5_CATAHU 2016.pdf.

[32] Pangkalan Data Pendidikan Tinggi Indonesia, "Statistik pendidikan tinggi," Jakarta, 2018.

[33] Pangkalan Data Pendidikan Tinggi Indonesia, "Statistik pendidikan tinggi," Jakarta, 2017. [Online]. Available: https://pddikti.ristekdikti.go.id/asset/data/publikasi/Statistik Pendidikan Tinggi Indonesia 2018.pdf.

[34] Ministry of Women's Empowerment and Child Protection Indonesia, "Policy brief: Gender equality in Indonesia," Jakarta, 2018. [Online]. Available: https://www.kemenpppa.go.id/lib/uploads/list/eec77-buku-policy-brief-genderequality.pdf.

[35] United Nations Educational Scientific and Cultural Organization, "A complex formula: Girls and women in science, technology, engineering and mathematics in Asia," Bangkok, 2015.

[36] Pangkalan Data Pendidikan Tinggi Indonesia, "Statistik pendidikan tinggi," Jakarta, 2019.

[37] Ministry of Research Technology and Higher Education Republic of Indonesia, "Laporan tahunan Kemenristekdikti 2018,” Jakarta, 2018.

[38] J. I. Suryakusuma, "The state and sexuality in new order Indonesia," in Fantasizing the feminine in indonesia, L. J. Sears, Ed. Durham: Duke University Press, 1996, pp. 92-119.

[39] Asian Development Bank, "Indonesia: Education sector analytical and capacity development partnership," Jakarta, 2018. [Online]. Available: https://www.adb.org/sites/default/files/project-documents/43273/43273-012-tcr-en.pdf. 